\title{
Effect of Different Priming Methods on Growth and Flowering of Different Flowers of Kashmir Valley, India
}

\author{
Sonam Dawa ${ }^{1 *}$, F.U. Khan', Neelofar ${ }^{2}$, F.A. Khan ${ }^{3}$, \\ Phunstog Tundup ${ }^{3}$ and Tsering Angdu ${ }^{4}$ \\ ${ }^{1}$ National Research Institute for Sowa-Rigpa (NRIS), Leh, J\&K, India \\ ${ }^{2}$ Division of FLA, SKUAST-K, Shalimar, Kolkata, India \\ ${ }^{3}$ Division of Soil Science, KVK-Leh, J\&K, India \\ ${ }^{4}$ National Research Institute for Sowa-Rigpa (NRIS), Leh, J\&K, India \\ *Corresponding author
}

\begin{tabular}{|c|c|}
\hline & A B S T R A C T \\
\hline & \multirow{6}{*}{$\begin{array}{l}\text { Seed priming is a process of regulating the germination process by managing the } \\
\text { temperature and seed moisture content, the seed is taken through the first biochemical } \\
\text { processes within the initial stages of germination. The priming process regulates the seed's } \\
\text { temperature and moisture content, bringing the seed closer to the point of germination. The } \\
\text { process involves advancing the seed to an equal stage of the germination process, to enable } \\
\text { fast and uniform emergence when planted. Seed priming is a treatment of seeds with } \\
\text { various priming agent for enhancement of germination and seedling quality besides } \\
\text { improving the growth and flowering of plants. There are various methods of priming agent } \\
\text { namely hydropriming which is a simple, economic and environmental friendly technique } \\
\text { of priming the seeds. This protocol has practical importance and could be recommended to } \\
\text { farmers to achieve higher germination, uniform emergence, improved growth, flowering } \\
\text { and yield characteristics of flowers. On the other hand priming methods like osmopriming } \\
\text { and nutripriming which uses different chemical priming agents like } \mathrm{KNO}_{3} \text {, Mannitol, } \\
\mathrm{KH}_{2} \mathrm{PO}_{4} \text { and NaCl of different concentrations dependent on the flower species to enhance } \\
\text { the germination percentage and uniformity of the plant growth. }\end{array}$} \\
\hline Keywords & \\
\hline $\begin{array}{l}\text { Priming, } \mathrm{NaCl} \text {, } \\
\text { Germination, } \\
\text { Uniformity and } \\
\text { mannitol. }\end{array}$ & \\
\hline Article Info & \\
\hline $\begin{array}{l}\text { Accepted: } \\
26 \text { October } 2017 \\
\text { Available Online: } \\
10 \text { December } 2017\end{array}$ & \\
\hline & \\
\hline
\end{tabular}

\section{Introduction}

\section{Effect of seed priming on germination attributes different flowers}

\section{Hydropriming}

Hydropriming is a simple, economic and environmental friendly technique of priming the seeds. This protocol has practical importance and could be recommended to farmers to achieve higher germination, uniform emergence, improved growth, flowering and yield characteristics in various crops as evidenced from reports by the various workers in this field.

Musa et al., (2014) conducted two field trials to evaluate the effect of hydropriming duration on the growth and yield of amaranth. Treatments consisted of four hydropriming durations (2, 4, 6, and 8 hours) and control (where no priming was applied). The treatments were laid out in a completely 
randomized design (CRD) replicated three times for the germination test and randomized complete block design (RCBD) for the field trial. Data were collected on days to $50 \%$ germination, percentage germination, days to $50 \%$ emergence, and percentage emergence.

Results revealed significant effect of hydropriming duration on days to $50 \%$ germination, percentage germination, and days to $50 \%$ emergence. Soaking seeds for 2 hours reduced the number of days to $50 \%$ germination and emergence and also recorded higher germination. Thus, from the findings of this study, it could be concluded that hydropriming amaranth seeds for 2 hours could be applied to enhance amaranth production.

Abbasi et al., (2013) carried out a trial to compare the efficacy of two seed priming techniques as well as osmopriming and hydropriming under salt stress on Agropyron elongatum germination. Seeds were immersed in -1.2 MPa PEG 6000 solutions for 24h for osmopriming and $12 \mathrm{~h}$ in water for hydropriming. Results revealed that germination, mean germination time, rate of germination and vigor index were negatively influenced by the increasing salt concentration of solution. Primed seeds were able to germinate at all concentrations of $\mathrm{NaCl}$ but germination was restricted at nonprimed seeds in -1.2 MPa. Both seed treatments spatially hydropriming gave better performance than untreated under salt stress of $A$. elongatum seeds.

Dastanpoor et al., (2013) studied the effect of hydropriming on Salvia officinalis L. at three temperatures $10,20,30^{\circ} \mathrm{C}$ for $0,12,24$ and $48 \mathrm{~h}$. Hydropriming clearly improved the final germination percentage (FGP), mean germination time (MGT) and synchronized the germination of seeds at each temperature.
All the seed treatments resulted in germination enhancement except hydroprimed seeds for $48 \mathrm{~h}$ at temperature $30^{\circ} \mathrm{C}$. However, hydropriming $\left(12 \mathrm{~h}\right.$ at $\left.30^{\circ} \mathrm{C}\right)$ was most effective in improving seed germination that FGP was increased by $25.5 \%$ as compared to the non-primed seeds.

$\mathrm{Gu}$ et al., (2012) in order to overcome the germination barriers occurred in triploid watermelon, seeds of three triploid watermelon cultivars were used to study the effect of hydropriming on germination by treating seeds under various priming treatments. Taking the perlite as solid medium, seeds were mixed in the medium and primed with distilled water at eight water content (30, 40, 50, 55, 60, 65, 70 and 80\%), followed by nine time $(12,24,30,36,42,48$, 54, 60 and 72h) at 15, 20 and $25^{\circ} \mathrm{C}$ respectively. Analysis of variance for laboratory data showed that hydropriming significantly improved germination rate, germination energy, root length, germination index and vigor index, compared to control (unprimed seeds) although different priming treatments resulted in a different seeds responses. However, among all the treatments, seeds primed with $60 \%$ perlite water content, priming for $36-48 \mathrm{~h}$ at $20^{\circ} \mathrm{C}$ gave the best results. Overall, seed priming of triploid watermelon was an effective, simple way to enhance uniform emergence and stand establishment.

Moghanibashi et al., (2012) carried out a laboratory experiment to evaluate the effect of aerated hydropriming (24h) on two cultivar of sunflower (Urfloar and Blazar) seed germination under a range of drought stress and salt stress. Cultivar Urfloar had the more germination rate $\left(\mathrm{R}_{50}\right)$, days to $50 \%$ germination $\left(\mathrm{D}_{50}\right)$, germination index $(\mathrm{GI})$, root and shoot length and dry weight as compared with cultivar Blazar. Hydropriming for $24 \mathrm{~h}$ increased germination percentage, 
germination rate, germination index, root and shoot length, root and shoot weight of seed sunflower as compared with the control. Primed seeds produced higher germination rate and percentage, $\mathrm{D}_{50}$ and GI under all salinity and drought levels as compared with non-primed seeds. The results suggested that hydropriming for $24 \mathrm{~h}$ was enhanced germination and seedling growth of sunflower under stress conditions. Therefore, this treatment may be used to improved seed performance of sunflower under normal and stress conditions.

Yucel (2012) in order to develop suitable techniques to improve lentil seed germination capacity, a research was conducted with cultivar Local Red lentil cultivar. Seeds were fully soaked in $\mathrm{KH}_{2} \mathrm{PO}_{4}(1 \%), \mathrm{KNO}_{3}(1 \%)$ solutions for osmopriming, and distilled water for hydropriming treatments, for 12 and 24 hours at a $24^{\circ} \mathrm{C}$ and untreated seeds as control. After the priming treatments, seeds were germinated at six different $(5,10,15$, 20,25 and $30 \pm 0.5^{\circ} \mathrm{C}$ ) constant temperatures. In terms of both germination percentage and MGT, the highest results were obtained from priming treatment of water at germination temperature of $20^{\circ} \mathrm{C}$ in priming times of $12 \mathrm{~h}$ and $24 \mathrm{~h}$. The best germination synchrony value was obtained from water treatment for $12 \mathrm{~h}$ at $15^{\circ} \mathrm{C}$. Consequently, seeds treated with water for $12 \mathrm{~h}$ produced the highest germination percentage and the least mean germination time and synchrony, in this way this treatment may be recommended for germination of lentil under different germination temperatures.

Anese et al., (2011) established a priming protocol for Solanum lycocarpum St. Hil., to improve germination of the dormant seeds and seedling development for in situ restoration, and to determine the mechanism underlying priming. Priming for 15 days at $15^{\circ} \mathrm{C}$ in water delivered the optimal priming effect, resulting in the fastest and most uniform germination and a high final germination percentage compared with shorter treatments, higher temperature and lower water potentials.

Ashraf and Razmjoo (2010) conducted a laboratory experiment to evaluate the effects of hydropriming (3 and 6hr) and osmopriming ( 3 and $6 \mathrm{hr} \mathrm{KNO}_{3}$ and $1 \mathrm{hr}$ polyethylene glycol (PEG) 6000 at $-0.2 \mathrm{MPa}$ ) on the germination of seeds from the safflower cultivar Kuseh. 6hr hydropriming treatment achieved the best results and significantly improved the germination, germination rate, germination uniformity and shoot/root ratio and decreased the time to $50 \%$ germination compared to control.

Bijanzadeh et al., (2010) studied to enhance the germination and emergence of rapeseed (Brassica napus L.) cv. Hyola 401 seeds using different priming treatments. Priming treatments examined were hydropriming, osmopriming with polyethylene glycol (PEG 6000), and solid matrix priming (SMP) with animal compost. Seeds from each of these 3 techniques were primed for 12 and 24 hours. Germination times and percentages, seedling growth, and electrical conductivity of seed leachates were measured. Solid matrix priming with compost was effective in improving germination percentage as compared to the non-primed control. Solid matrix priming with compost for 12 and 24 hours, and hydropriming for 24 hours were the most efficient techniques for reducing the mean germination time. Highest electrical conductivity was recorded for the control group and seeds osmo-primed with PEG 6000 and the lowest electrical conductivity in hydro-primed and SMP treatments after 12 and 24 hours. During emergence tests, the SMP treatment for 24 hours reduced the mean emergence time and also recorded the highest final emergence. The greatest root and shoot 
lengths were however recorded in hydroprimed seeds after 24 hours. It was concluded that SMP for 12 and 24 hours was the most effective treatment in improving overall germination and seedling emergence of rapeseed.

Ramzan et al., (2010) used various concentrations of $\mathrm{KNO}_{3}(1,2,3,4$ and 5\%), distilled water and control in gladiolus. They reported that best germination rate, minimum time required for $50 \%$ germination, shortest mean germination time, maximum seedling length, maximum bulb weight and diameter were obtained with distilled water primed seeds as compared to $\mathrm{KNO}_{3}$ concentrations and control.

In an another study on aged coriander (Coriandrum sativum L.) seeds, Rithichia et al., (2009) observed that hydropriming of seeds for 8 hours incubated at $20^{\circ} \mathrm{C}$ for 24 hours resulted in earlier germination, recorded higher first count as well as more germination percentage in comparison to primed seeds, irrespective of ageing duration.

Pegah et al., (2008) conducted study to evaluate the influence of seed priming techniques on germination and early growth of two maize inbred lines including B73 and MO17. Seeds were hydroprimed for 12, 24, 36 and 48h, osmoprimed in urea solution and in solution of polyethylene glycol-6000 (PEG-6000) for 96h (4 days) (water potential -1.2 MPa). Priming techniques affected seed germination and early growth of both inbred lines. Hydropriming resulted in lower time taken to germination and higher germination index, vigor index and final germination percentage in both genotypes. Maximum invigoration was observed in seeds hydroprimed for $36 \mathrm{~h}$ as indicated by higher germination rate, radical length. Conversely, for most germination parameters osmoprimed seeds behaved similar to or even poor than that of control.
Khan et al., (2003) soaked the seeds of 3 sunflower genotypes in water for 24 hours then dried back to its original moisture level and dry dressing with $(0.25 \%)$ thiram, which significantly enhanced germination percentage, field emergence, root length, shoot length and vigor index, respectively in APSH-11, 7-1B \& 1A. The promotive effects were observed on seed germination of two triploid watermelon cultivars 'Gold Prince' and 'Guangxi 5', when subjected to hydropriming by soaking in de-ionized water for 2 hours with aeration following 24 and 48 hours incubation at saturated relative humidity (Huang et al., 2002). Similarly, in another experiment on Helichrysum bractaetum, it was noticed that hydropriming for 6 days at $15^{\circ} \mathrm{C}$ accelerated germination and also did not inhibit germination percentage when maintained at $5-30^{\circ} \mathrm{C}$ after conditioning (Bush, 2006).

The effects of hydration (with water or dilute solutions of $\mathrm{NaCl}$ ) and dehydration followed by storage for 0 or 12 month were studied in sunflower seeds and it was concluded that priming treatments both with water and dilute solutions of $\mathrm{NaCl}$ were effective in retaining the seed viability and seedling vigor after subsequent storage. Plant density and seed yield were also higher from treated seeds than untreated seeds even for 12 months (Singh, 1995).

\section{Osmopriming}

Dkhil et al., (2014) conducted an experiment to evaluate the effects of priming on the germination, emergence and seedling growth of Abelmoschus esculentus (cultivar Marsaouia) under low temperature and salinity conditions. Seeds were primed for $24 \mathrm{~h}$ at $20^{\circ} \mathrm{C}$ in three priming media $(\mathrm{KCl} 4 \%$, mannitol $0.75 \mathrm{M}, \mathrm{CaCl}_{2} 10 \mathrm{Mm}$ ) and control (non-primed seeds) and were examined at different salinity levels $(0,40$ and $100 \mathrm{mM}$ 
$\mathrm{NaCl}$ ). Result indicated that $\mathrm{KCl}$ priming increased final germination percentage, radicle length and seedling dry weight $100 \%$, $40.94 \mathrm{~mm}$ and $0.3 \mathrm{~g}$, respectively, as compared with non-primed seeds. Mannitol and $\mathrm{CaCl}_{2}$ have been found to be better treatments for improving final emergence percentage. Overall increased $\mathrm{NaCl}$ level, led to the reductions in final germination and emergence percentage but these reductions were higher for non-primed compared to primed seeds.

Golmohammadzadeh et al., (2014) examined the effects of some priming treatments including hydropriming, gibberellic acid $\left(\mathrm{GA}_{3}\right)$, potassium nitrate $\left(\mathrm{KNO}_{3}\right)$, priming duration and light regime on seed dormancy breaking of Papaver rhoeas and P. dubium. The result showed that all treatments significantly stimulated germination of both Papaver species. Soaking seeds in distilled water led to significant increase in germination in both species. Maximum germination percentage was observed for $24 \mathrm{~h}$ hydropriming treatments $(32.4 \%$ for $P$. dubium and $34.6 \%$ for $P$. rhoeas) in light/dark condition. In general $0.5 \quad \mathrm{~g}^{-1} \quad \mathrm{KNO}_{3}$ treatments resulted in more vigorous seed germination in both species at any duration compared to any other concentration of the potassium nitrate. In both species the highest seed germination was achieved when the seeds were treated $24 \mathrm{~h}$ with $0.5 \mathrm{~g} \mathrm{l}^{-1} \mathrm{KNO}_{3}$ solution but it was decreased in $6 \mathrm{~g} \mathrm{l}^{-1}$. Among the priming treatments with $\mathrm{GA}_{3}$, the highest germination of both species was recorded in seed treated with 500 and 750 ppm $\mathrm{GA}_{3}$ respectively in $P$. dubium and $P$. rhoeas for $48 \mathrm{~h}$.

Abbaszadeh et al., (2012) conducted an experiment in factorial in the form of a completely randomized design with three replications. Treatments included population (from Arak, Hamedan and Shahrekord habitats), temperature $\left(10,25\right.$ and $\left.35^{\circ} \mathrm{C}\right)$ and drought stress induced by polyethylene glycol $(0,-2,-4,-6,-8,-10$ and -12 osmotic potential bars). Results indicated the significant effect of habitat, temperature and drought on all the measured traits. The interactions had also a significant effect on most of the measured traits. Seeds of samples collected from Shahrekord habitat had the highest germination. Among the temperature treatments, $25^{\circ} \mathrm{C}$ was the most favourable for seeds germination.

Silva et al., (2012) conducted a study to evaluate the germination of hot pepper 'Mari' at different temperatures after osmotic conditioning. Seeds were conditioned in aerated solution of polyethylene glycol (PEG 6000 ) for a period of seven days. Seeds were incubated at $15,20,25,30$ and $35^{\circ} \mathrm{C}$. Seed counting were made daily to assess the germination rate. The total seed germination decreased with increasing temperature. In the first counting the conditioned seeds differed from non-conditioned at $35^{\circ} \mathrm{C}$. The osmotic conditioning was effective in improving seed germination at all temperatures, especially at high temperatures.

Afzal et al., (2011) carried out a laboratory study to investigate the influence of priming with mannitol (2, 4 and $6 \%)$ on germination and seedling growth of African and French marigold seeds. Priming with 2 and 4\% mannitol for $24 \mathrm{~h}$ maximally increased final germination percentage, germination capacity, germination index, shoot and root lengths of both marigold species as compared to all presowing seed treatments including control. Similarly, at those concentrations mannitol significantly reduced mean emergence time and days to $50 \%$ emergence, increased seedling emergence uniformity, final seedling emergence percentage and seedling growth. In conclusion, priming with $2 \%$ mannitol proved to be the most effective priming agent 
in both marigold cultivars. This could be attributed to the effect of mannitol in increasing reducing and total sugars as well as $\alpha$-amylase activity in primed seeds.

Natarajan and Shrimathi (2006) evaluated the effect of seed priming on seed and seedling quality of petunia cv. Mix. When treated with PEG (polyethylene glycol) and mannitol at various pressures $(-5,-10$ and -15$)$ and durations (3, 6, 9, 12 and 15 days). Priming with PEG improved germination by $11 \%$ when compared to mannitol. A rate of -15 bar showed higher germination than the other rates. A duration of 3 days resulted in higher seed and seedling quality parameters.

\section{Nutripriming}

Mirlotfi et al., (2015) an experiment was conducted in laboratory and greenhouse to investigate the effect of salinity and priming on seed germination and other plant traits of calendula. Two separate factorial experiment based on randomized complete block design with three replications was conducted. Treatments were four priming levels (distilled water, $0.1 \%$ solution of manganese sulfate, $0.5 \%$ solution of calcium sulfate, $0.6 \%$ solution of potassium phosphate, control) and four salinity levels (S1: 0, S: 25, S3: 50 and $\mathrm{S} 4: 75 \mathrm{mmol} / \mathrm{lit}$ solutions of $\mathrm{NaCl}$ ). Germination rate promoted by priming treatments which result in better establishment. Stem length and root length reduced by salinity. Root length enhanced by applying distilled water as priming treatment. Root dry weight enhanced by salinity. Root dry weight at $75 \mathrm{mmol} / \mathrm{lit} \mathrm{NaCl}$ level, enhanced by applying manganese sulfate as priming treatment. Chlorophyll and carotenoid content did not affect by salinity levels and priming treatments.

Canak et al., (2014) conducted an experiment in order to assess the effect of seed priming on four germination parameters (germination, germination index, mean germination time and time to $50 \%$ germination) of sunflower in in vitro drought conditions. Drought conditions (-0.8 MPa) were simulated using PEG 6000. Seed priming was conducted with soaking seed in water and different $\mathrm{KNO}_{3}$ solutions $(0.1,0.5$ and $1 \%)$ for $12 \mathrm{~h}$. Seed priming treatment with $0.1 \% \mathrm{KNO}_{3}$ showed the best results and improved germination parameters: germination index, mean germination time and time to 50\% germination of untreated seed (control). Seed priming showed no improvement in germination percentage in comparison to the control.

Hadinezhad et al., (2013) studied the effect of seed priming treatments on germination characters and seedling growth in Quercus castaneifolia, a native commercial tree species of northern Iran. Seeds were collected in January 2010 and primed for 1 or 4 days in $1,1.5$ or $3 \% \mathrm{KNO}_{3}$ or in tap water for 12,24 or 48 hours. Priming improved the germination index, seedling diameter, seedling length, and dry weight; mean germination time decreased. The highest seedling length, seedling diameter and dry weight were also obtained following $\mathrm{KNO}_{3}$ treatments. We conclude that $1.5 \% \quad \mathrm{KNO}_{3}$ would be a useful treatment to improve seedling production and vigor of $Q$. castaneifolia seeds for use in restoration programmes. Farhoudi (2012) reported that $\mathrm{KNO}_{3}$ priming of sunflower seeds, especially 0.6 and $0.9 \mathrm{MPa} \mathrm{KNO}_{3}$ solution, was more effective than non-priming seeds under salinity condition. Results showed sunflower germination percentage, seedling fresh weight and seedling growth decreases under salinity condition but mean germination time and malondealdehyde concentration was increased. Results showed under saline condition seed priming with $\mathrm{KNO}_{3}$ improved unflower seed germination, peroxidase 
activity and seedling growth compared non priming seeds.

Mushtaq et al., (2012) evaluated the effect of different priming treatments on germination behavior of Gladiolus alatus. Seed priming was done with different concentration of potassium nitrate $\left(\mathrm{KNO}_{3}\right)$ and hydropriming. All the treatment had significant effect on germination percentage, germination test in growth room, time for $50 \%$ germination and mean germination time. Results show that maximum invigoration was observed in seeds osmoprimed at lower concentrations of $\mathrm{KNO}_{3}$ and with hydropriming while minimum invigoration was observed at higher concentration of $\mathrm{KNO}_{3}$. It was concluded that germination percentage can be increased by using lower concentrations of $\mathrm{KNO}_{3}$ and with hydropriming.

Zahedi et al., (2012) conducted a laboratory research to study the effects of seed priming on germination and initial growth of Dianthus barbatus seeds compared with controls (unprimed). In this experiment, Sweet William seeds were placed for $24 \mathrm{~h}$ in solutions $\mathrm{GA}_{3}$ (with two concentrations 50 and $100 \mathrm{ppm}), \mathrm{KNO}_{3}(0.5$ and $1 \%), \mathrm{KH}_{2} \mathrm{PO}_{4}$ (1 and $2.5 \%$ ). After completion of priming, seeds were dried at room temperature and dark conditions. For evaluation behavior of germination, 20 seeds from each treatment was placed within the petri dish between two layers of filter paper, in $5 \mathrm{ml}$ distilled water to each petri dish was added, for germination was transferred germinator $2 \pm 25^{\circ} \mathrm{C}$.

Design was used in this study based on factorial Completely Randomized Design. At the end of germination were evaluated traits such as root length, shoot length, germination percentage, and dry weight plant. Test results showed that seed treatment with gibberellin solution concentration of $100 \mathrm{ppm}$ was significant germination, root length, and shoot length in comparison with other treatments as a significant level of $5 \%$.

Jeong et al., (2000) studied the effect of chemicals and their concentrations, priming temperature and duration and different germination temperature on germinability of Salvia splendens seeds. The highest percentage of germination was obtained with 50 or $100 \mathrm{mM} \mathrm{KH}{ }_{2} \mathrm{PO}_{4}$ or -0.5 or $-0.75 \mathrm{MPa}$ PEG 8000. Priming the seeds at $20^{\circ} \mathrm{C}$ was better than priming at 15 or $25^{\circ} \mathrm{C}$. Seeds primed with $-0.50 \mathrm{MPa}$ PEG at $20^{\circ} \mathrm{C}$ showed a high germination percentage with reduced $\mathrm{T}_{50}$ and $\mathrm{MDG}$ (mean number of days to germination). When seeds were primed in a mixture of $-0.50 \mathrm{MPa}$ PEG and $50 \mathrm{mM}$ $\mathrm{KH}_{2} \mathrm{PO}_{4}$ solution and germinated at 30 or $35^{\circ} \mathrm{C}$, percentage germination was lower than in non-primed seeds.

Bush et al., (2000) reported that priming or pre-soaking seed of common carpet grass (Axonopus affinis Chase) and centipede grass [Eremochloa ophiuroides Munro (Kunz)] increased germination percentage and decreased mean time of germination (MTG) at 20,25 , and $30^{\circ} \mathrm{C}$. The effect of pre-soaking and priming was dependent on grass species and temperature.

The optimum seed germination temperature for both of these warm-season species was $30^{\circ} \mathrm{C}$. Maximum effect on common carpet grass or centipede grass seeds was achieved by priming in $2 \% \quad \mathrm{KNO}_{3} ;$ higher concentrations did not improve germination percentage or MTG, and $4 \%$ was in some cases detrimental.

Germination was higher and MTG lower at 20 and $30^{\circ} \mathrm{C}$ than at $15^{\circ} \mathrm{C}$. Pre-soaking common carpet grass and centipede grass seeds was the most efficient seed enhancement treatment for germination at $30^{\circ} \mathrm{C}$. 
Effect of seed priming on seedling emergence and plant growth

\section{Hydropriming}

Mir-Mahmoodi et al., (2013) conducted a field experiments and laboratory evaluations to investigate the effects of hydropriming durations on sunflower seed. Field tests were conducted in a RCB design in 2011 and 2012 to evaluate the effects of various durations of hydropriming treatment on evaluations for seed germination, seedling vigor and field establishment of sunflower seeds. Seeds were divided into five sample sets, one of which was used as the control (non-primed) and the other four sample sets were soaked in distilled water for durations of $6,12,18$ and $24 \mathrm{~h}$ and then dried off to reach a moisture content of about $10-12 \%$. Linear regression showed that a longer duration of hydropriming improved evaluations for germination percentage and mean time for germination. Records were taken for seed response in terms of dry weight of shoot, root and seedling and electrical conductivity. Evaluations for dry weight max, root dry weight max and seedling dry weight max were obtained from durations of 13.7, 15.1 and $14.3 \mathrm{~h}$ hydropriming respectively. The lowest evaluation for electrical conductivity was recorded in the hydropriming duration of $7.15 \mathrm{~h}$. This resulted in better stand establishment of seedlings from primed seeds and the optimum duration of hydropriming sunflower seeds was recorded in the range of 13.7-15.1h. Hydropriming in field conditions enhanced evaluations for percentage of seedling emergence $(0.63 \% / 1 \mathrm{~h}$ priming) and reduced time to emergence $(-0.29 \mathrm{~h} / 1$ priming). Thus, hydropriming presents a simple method for improving seed germination and seedling emergence of sunflower in field conditions.

In an experiment, seeds of sunflower were hydroprimed for 24 hours, hardened for 24 hours, matrix-primed for 24 hours and 48 hours, osmoprimed with $0.5 \% \mathrm{KNO}_{3}$ for 12 hours and with $0.1 \% \mathrm{NaCl}$ for 14 hours. Hydropriming and osmopriming with $\mathrm{NaCl}$ resulted in lower time taken to 50\% emergence and mean emergence time and higher final emergence, energy of emergence, plant population but time taken to seedling emergence and plant height were not affected significantly by different seed priming treatments (Hussain et al., 2008).

\section{Nutripriming}

Jaghargh et al., (2014) studied the effects of six different treatments on enhancement the emergence of species of Anthemis seeds. Treatments of seeds included seed priming with potassium nitrate (with concentrations 0.5 and 1\%), gibberellic acid (with concentrations 125 and $250 \mathrm{ppm}$ ), distilled water (as control) and pre-chilling $\left(4^{\circ} \mathrm{C}\right.$ for 14 days). Comparison of seed germination characteristics and seedlings vigor of four Anthemis species (Anthemis altissima, Anthemis haussknechtii, Anthemis pseudocotula and Anthemis tinctoria) showed that species of $A$. altissima had higher percentage and speed of emergence, ratio of rootlet length by shootlet length, vigor index, dry weight of seedling and leaf area than three species of Anthemis. The results indicated that seed priming with 125 and $250 \mathrm{ppm}$ gibberellic acid improved emergence percentage (94\%), speed of emergence (18.54 sprout/day) and vigor index (83.29) species of A. altissima. The highest dry weight (358.1 $\mathrm{mg}$ ) was found in primed seeds with 0.5 and $1 \%$ potassium nitrate species of A. altissima. In conclusion, primed seeds with gibberellic acid and potassium nitrate (osmopriming) improved species of Anthemis germination potential and seedlings growth in greenhouse.

Hamidi and Pirasteh-Anosheh (2013) conducted the study to evaluate the effect of 
polyethylene glycol (PEG), urea and potassium nitrate $\left(\mathrm{KNO}_{3}\right)$ priming on sunflower germination traits and early growth. The study included two experiments based on completely randomized design (CRD) with four replicates. The first and second experiment consisted of comparison between urea with PEG and $\mathrm{KNO}_{3}$ with PEG, respectively; each priming method had four levels $(0.00,-0.05,-0.10$ and -0.15 bar). The result showed that urea and $\mathrm{KNO}_{3}$ priming had no positive and significant effect on germination percentage, while significantly increased both radicle and shoot length. Also PEG in both experiments significantly decreased germination percentage and increased seedling growth. Increasing effect of urea and $\mathrm{KNO}_{3}$ seed priming on seedling growth was more than PEG, thus these increasing effect of urea and $\mathrm{KNO}_{3}$ priming could be due to seed nutrition.

Qadir et al., (2011) studied the potential of seed priming techniques in improving germination and early seedling growth of three rangeland grasses (viz. buffel grass (Cenchrus ciliaris L.), dhaman grass ( $C$. setigerus Vahal), and blue panic grass (Panicum antidotale Retz.) was evaluated in a laboratory trial. For priming, seeds were soaked in well aerated solution of $\mathrm{CaCl}_{2}$, $\mathrm{KNO}_{3}, \mathrm{KCl}$ and $\mathrm{CaSO}_{4}$ (each having 10 and $50 \mathrm{mM}$ solution) for $24 \mathrm{~h}$. Both hydropriming and untreated seeds were considered as control treatments. Maximum germination of buffel grass was recorded from osmopriming $\left(10 \mathrm{mM} \mathrm{KNO}_{3}\right)$ while in dhaman and blue panic grass low concentration of $\mathrm{CaSO}_{3} 10$ $\mathrm{mM}$ followed by priming with $50 \mathrm{mM} \mathrm{KNO}_{3}$ proved the best. Maximum plumule length was recorded in $\mathrm{CaSO}_{4}$ and $50 \mathrm{mM} \mathrm{CaCl}$ while less mean germination time (1.91 and 2.06) was recorded in untreated control and $10 \mathrm{mM} \mathrm{CaCl}{ }_{2}$ respectively. Osmopriming with $10 \mathrm{mM}$ or $50 \mathrm{mM} \mathrm{KNO}_{3}$ can be successfully employed to improve the germination and seedling vigor in bufffel grass and low level of $\mathrm{CaSO}_{4}$ to improved dhaman grass and panic grass performance in rangeland.

Kanthiresan et al., (1984) reported that the field emergence and early seedling growth of sunflower were improved by soaking seeds in $\mathrm{KH}_{2} \mathrm{PO}_{4}(2.0 \%)$ solution. The increase in seedling vigor was associated with enhanced oxygen uptake and increased amylase activity and efficiency of metabolizing nutrients from the cotyledons to the embryonic axis.

\section{Effect of seed priming on flowering and seed yield of different flowers}

\section{Hydropriming}

Ghassemi-Golezani et al., (2010) conducted a field study, in which hydropriming for 7 and 14 hours resulted in lower mean emergence time, higher seedling emergence percentage, grains $/ \mathrm{m}^{2}$, grain yield $/ \mathrm{m}^{2}$, grains/plant, 1000 grain weight and grain yield per unit area.

\section{Osmopriming}

Narayanareddy and Biradarpatil (2012) an investigation was undertaken in order to know the effect of pre-sowing invigoration seed treatments on seed quality and crop establishment in sunflower hybrid KBSH-1. The different pre-sowing invigoration seed treatments showed differential response for all the seed quality attributes, growth and yield parameters. Among the treatments, seeds treated with two per cent $\mathrm{CaCl}_{2}$ for $12 \mathrm{~h}$ and drying back to original moisture content at room temperature recorded significantly higher germination percentage $(86.6 \%)$, seedling vigour index (2243), field emergence $(81.50 \%)$, lesser days for 50 per cent flowering (58.2) and yield per ha (11.83 q/ha) followed by $\mathrm{GA}_{3}$ treatment and water hydration. 


\section{Nutripriming}

Kalpana et al., (2015) conducted an experiment to study the effect of seed priming on germination, growth, biochemical changes and yield of tolerant KRL 210 and susceptible HD 2733 varieties under sodic soil. Seed priming was done by soaking the seeds for 12 hours in distilled water, $\mathrm{KNO}_{3}(3 \%), \mathrm{KCl}$ $(1 \%), \mathrm{GA}_{3}(150 \mathrm{ppm})$ and cycocel $500 \mathrm{ppm}$. Application of primers brought a considerable increase in germination and growth parameters like plant height, tiller numbers and plant dry weight. The biochemical parameters viz., total chlorophyll content and starch content showed a significant increase due to seed priming. Seed priming also significantly enhanced the ear bearing tiller plant $^{-1}$, number of grain ear ${ }^{-1}$ and grain yield plant ${ }^{-1}$. Among different treatments, $\mathrm{KNO}_{3}$ (3\%) was found superior among all the priming treatments and significantly higher than rest of the treatments.

\section{References}

Abbasi, M., Azarnivand, H., Alizadeh, O. and Hedayati, A. 2013. Seed treatments to improve germination of Agropyron elongatum seeds under salt stress. International Journal of Agronomy and Plant Production 4(4): 603-609.

Abbaszadeh, B., Ardakani, M. R., Haghighi, M. L. and Changaei, N. 2012. Response of three camphor populations germination to different temperatures and polyethylene glycol induced drought stress. Annals of Biological Research 3(9): 4393-4399.

Afzal, I., Ashraf, S., Qasim, M., Basra, S.M.A., Shahid, M. and Hussain, B. 2011. Mannitol priming induces biochemical changes and enhances germination capacity and seedling vigor in marigold (Tagetes spp.). Acta Horticulturae 898: 25-29.

Anese, S., Silva, E.A.A.D., Davide, A.C., Faria, J.M.R., Soares, G.C.M., Matos, A.C.B. and Toorop, P.E. 2011. Seed priming improves endosperm weakening, germination and subsequent seedling development of Solanum lycocarpum St. Hil. Seed Science and Technology 39: 125-139.

Ashraf, M. and Folad, M.R. 2005. Pre-sowing seed treatment-A shotgun approach to improve germination, plant growth and crop yield under saline and non-saline conditions. Advances in Agronomy 88: 223-265.

Bijanzadeh, E., Nosrati, K. and Egan, T. 2010. Influence of seed priming techniques on germination and emergence of rapeseed (Brassica napus L.). Seed Science and Technology 38(1): 242-247.

Bush, E.W., Wilson, P., Shepard, D.P. and Mc Clure, G. 2000a. Enhancement of seed germination in common carpetgrass and centipedegrass Seed. HortScience 35(4): 769-770.

Bush, E.W., Wilson, P., Shepard, D.P. and Mc Clure, G. 2000b. Enhancement of seed germination in common carpetgrass and centipedegrass Seed. HortScience 35(4): 769-770.

Canak, P., Jockovic, M., Ciric, M., Mirosavljevic, M. and Miklic, V. 2014. Effect of seed priming with various concentrations of $\mathrm{KNO}_{3}$ on sunflower seed germination parameters in in vitro drought conditions. Research on Crops 15(1): 154-158.

Dastanpoor, N., Fahimi, H., Shariati, M., Davazdahemami, S. and Hashemi, S.M.M. 2013. Effects of hydro-priming on seed germination and seedling growth in sage (Salvia officinalis L.). African Journal of Biotechnology 12(11): 1223-1228.

Dkhil, B.B., Issa, A. and Denden, M. 2014. Germination and seedling emergence of primed okra (Abelmoschus esculentus L.) seeds under salt stress and low temperature. American Journal of Plant Physiology 9(2): 38-45.

Farhoudi, R. 2012. Evaluation effect of $\mathrm{KNO}_{3}$ seed priming on seedling growth and 
cell membrane damage of sunflower (Helianthus annus) under salt stress. American Eurasian Journal of Agricultural and Environmental Sciences 12(3): 384-388.

Ghassemi-Golezani, K., Chadordooz-Jeddi, A., Nasrullahzadeh, S. and Moghaddam, M. 2010. Influence of hydro-priming duration on field performance of pinto bean (Phaseolus vulgaris L.) cultivars. African Journal of Agricultural Research 5(9): 893-897.

Golmohammadzadeh, S., Zaefarian, F. and Rezvani, M. 2014. Investigation of different priming techniques on seed germination of papaver species. International Journal of Biosciences 4(3): 1-9.

Gu, G., Xu, Q., Zhang, X. and Liang, Q. 2012. Effect of hydro-priming on seed germination of triploid watermelon (Citrullus lanatus (Thunb) Matsum \& Nakai). Acta Horticulturae 871(1): 119126.

Hadinezhad, P., Payamenur, V., Mohamadi, J. and Ghaderifar, F. 2013. The effect of priming on seed germination and seedling growth in Quercus castaneifolia. Seed Science and Technology 41(1): 121-124.

Hamidi, R. and Pirasteh-Anosheh, H. 2013. Comparison effect of different seed priming methods on sunflower germination and seedling growth. International Journal of Agronomy and Plant Production 4(6): 1247-1250.

Huang, R., Sukpaprakaran, S., Thongket, T. and Juntakool, S. 2002. Effect of hydropriming and redrying on the germination of triploid watermelon seeds. Kasetsart Journal: (Natural Science) 36(3): 219224.

Hussain, M., Farooq, M., Basra, S.M.A. and Ahmad, N. 2008. Influence of seed priming techniques on the seedling establishment yield and quality of hybrid sunflower. International Journal of Agriculture and Biology 8(1): 14-18.

Jaghargh, S.S.S., Alizadeh, M.A. and Kalagari,
M. 2014. Effect of osmo-priming, hydro-priming and pre-chilling on seed emergence enhancement and seedling vigor of four medicinal species of Anthemis under greenhouse conditions. Bulletin UASVM Horticulture 71(1): 7484.

Jeong, Y.O., Kang, S.M. and Cho, J.L. 2000. Priming conditions to improve germination of (Salvia splendens F.) seeds. Korean Journal of Horticultural Science and Technology 18(2): 98-102.

Kalpana., Khan, A. H., Singh, A. K., Maurya, K. N., Mubeen., Yadava, R. K., Singh, U. and Gautam. A.R. 2015. Effect of different seed priming treatments on germination, growth, biochemical changes and yield of wheat varieties under sodic soil. International Journal of Science and Research 4(7): 306-310.

Kathiresan, K., Kalyani, V. and Gnanarethinam, J.L. 1984. Effect of seed treatments on field emergence, early growth and some physiological process of sunflower (Helianthus annuus L). Field Crop Research 9(3\&4): 215-217.

Khan, G.M., Keshavulu. K., Reddy, B.M. and Radhika, K. 2003. Effect of pre-sowing seed treatments on the establishment of sunflower. Seed Research 31(1): 94-97.

Mir-Mahmoodi, T., Khaliliaqdam, N., Pirmani, A., Yazdan-Sta, S. and Sharafi, S. 2013. Effects of hydropriming on laboratory indexes and field performance of sunflower seeds. International Journal of AgriScience 3(12): 904-911.

Mirlotfi, A., Bakhtiari, S. and Bazrgar, A.B. 2015. Effect of seed priming on germination and seedling traits of marigold (Calendula officinalis) at saline condition. Biological Forum-An International Journal 7(1): 1626-1630.

Moghanibashi, M., Karimmojeni, H., Nikneshan, P. and Behrozi, D. 2012. Effect of hydropriming on seed germination indices of sunflower (Helianthus annuus L.) under salt and drought conditions. Plant Knowledge Journal 1(1): 10-15. 
Musa, M., Singh, A. and Lawal, A.A. 2014. Influence of priming duration on the performance of amaranthus (Amaranthus cruentus L.) in Sokoto Semiarid Zone of Nigeria. International Journal of Agronomy: 1-4.

Mushtaq, S., Hafiz, I.A., Hasan, S.Z.U., Arif, M., Shehzad, M.A., Rafique, R., Rasheed, M., Ali, M. and Iqbal, M.S. 2012. Evaluation of seed priming on germination of Gladiolus alatus. African Journal of Biotechnology 11(52): 11520-11523.

Narayanareddy, A.B. and Biradarpatil, N.K. 2012. Effect of pre-sowing invigoration seed treatments on seed quality and crop establishment in sunflower hybrid KBSH-1. Karnataka Journal of Agricultural Sciences 25(1): 43-46.

Natarajan, K. and Shrimathi, P. 2006. Influence of seed priming treatments on seed and seedling quality of petunia cv. Mix. Annals of Plant Physiology 20(2): 192196.

Pegah, M. D., Farzad, S. and Mohsen, J. 2008. Influence of priming techniques on seed germination behaviour of maize inbred lines (Zea mays L.). Journal of Agricultural and Biological Science 3(3): 22-25.

Qadir, I., Khan, Z. H., Khan, R. A. and. Afzal, I. 2011. Evaluating the potential of seed priming techniques in improving germination and early seedling growth of various rangeland grasses. Pakistan Journal of Botany 43(6): 2797-2800.
Ramzan, A., Hafiz, I.A., Ahmad, T. and Abbasi, N.A. 2010. Effect of priming with potassium nitrate and dehusking on seed germination of gladiolus (Gladiolus alatus). Pakistan Journal of Botany 42(1): 247-258.

Rithichai, P., Sampantharat, P. and Jirakiattikul, Y. 2009. Coriander (Coriandrum sativum L.) seed quality as affected by accelerated aging and subsequent hydropriming. Asian Journal of Food and Agro-Industry (Special Issue): 217221.

Silva, P.P., Freitas, R.A. and Nascimento, W.M. 2012. Hot Pepper seed priming and germination at different temperatures. Acta Horticulturae 932: 341-343.

Singh, H. 1995. Effect of hydro-priming and halo-priming on vigor of sunflower seeds. Agriculture Science Digest 9: 160-165.

Yucel, D.O. 2012. The effect of different priming treatments and germination temperatures on germination performance of lentil (Lens culinaris medik) seeds. Journal of Agricultural and Biological Science 7(12): 977-981.

Zahedi, S.M., Azizi, M. and Gheysari, H. 2012. Effect of seed priming on germination and initial growth of Sweet William (Dianthus barbatus). Annals of Biological Research 3(8): 4192-4194.

\section{How to cite this article:}

Sonam Dawa, F.U. Khan, Neelofar, F.A. Khan, Phunstog Tundup and Tsering Angdu. 2017. Effect of Different Priming Methods on Growth and Flowering of Different Flowers of Kashmir Valley, India. Int.J.Curr.Microbiol.App.Sci. 6(12): 3333-3344. doi: https://doi.org/10.20546/ijcmas.2017.612.388 